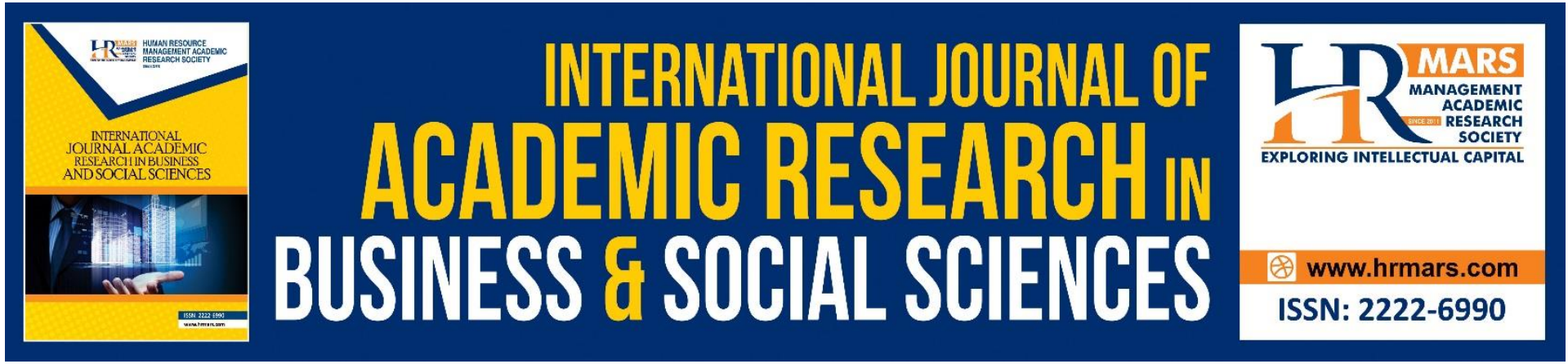

\title{
Quality of Financial Reporting towards the Improvement Corporate Governance Mechanism
}

Norfadzilah Rashid, Wan Norhayate Wan Daud, Fakhrul Anwar Zainol, Fauzilah Salleh, Ahmad Shukri Yazid, Wan Anisah Endut, Noryati Yaakub, Puspa Liza Ghazali, Asyraf Afthanorhan

To Link this Article: http://dx.doi.org/10.6007/IJARBSS/v8-i11/5175 DOI: 10.6007/IJARBSS/v8-i11/5175

Received: 07 Nov 2018, Revised: 26 Nov 2018, Accepted: 02 Dec 2018

Published Online: 04 Dec 2018

In-Text Citation: (Rashid et al., 2018)

To Cite this Article: Rashid, N., Daud, W. N. W., Zainol, F. A., Salleh, F., Yazid, A. S., Endut, W. A., ... Afthanorhan, A. (2018). Quality of Financial Reporting towards the Improvement Corporate Governance Mechanism. International Journal of Academic Research in Business and Social Sciences, 8(11), 1339-1345.

Copyright: () 2018 The Author(s)

Published by Human Resource Management Academic Research Society (www.hrmars.com)

This article is published under the Creative Commons Attribution (CC BY 4.0) license. Anyone may reproduce, distribute, translate and create derivative works of this article (for both commercial and non-commercial purposes), subject to full attribution to the original publication and authors. The full terms of this license may be seen at: http://creativecommons.org/licences/by/4.0/legalcode

Vol. 8, No. 11, 2018, Pg. 1339 - 1345

Full Terms \& Conditions of access and use can be found at http://hrmars.com/index.php/pages/detail/publication-ethics 


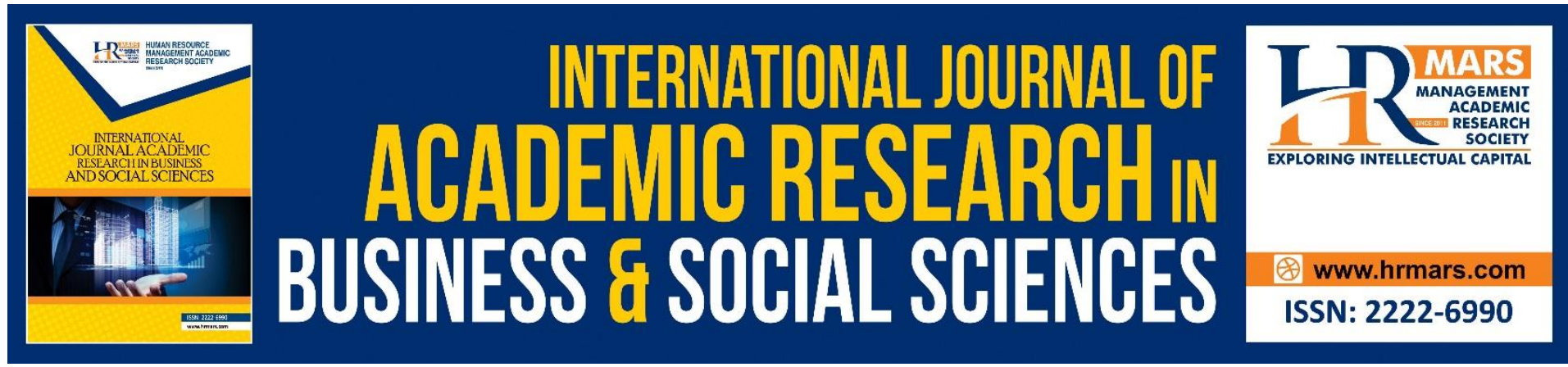

\title{
Quality of Financial Reporting towards the Improvement Corporate Governance Mechanism
}

\author{
${ }^{1}$ Norfadzilah Rashid, ${ }^{2}$ Wan Norhayate Wan Daud, ${ }^{3}$ Fakhrul \\ Anwar Zainol, ${ }^{4}$ Fauzilah Salleh, ${ }^{5}$ Ahmad Shukri Yazid, ${ }^{6}$ Wan \\ Anisah Endut, ${ }^{7}$ Noryati Yaakub, ${ }^{8} \mathrm{Puspa}$ Liza Ghazali, ${ }^{9}$ Asyraf \\ Afthanorhan \\ $1,2,3,4,5,6,7,8,9$ Faculty of Economics and Management Sciences, Universiti Sultan Zainal Abidin, \\ Gong Badak Campus, 21300 Kuala Nerus, Terengganu, Malaysia
}

\begin{abstract}
International Financial Reporting Standards is a set of high-quality, understandable, enforceable and globally accepted accounting standards used by companies to prepare financial statements (IFRS Foundation, 2001). IFRS was established in 2001 by International Accounting Standards Board (IASB) which operates as the independent standard-setting body of the IFRS Foundation. This accounting standard is being adopted by more than 100 countries in the world. However, some amendments been made according to certain countries' requirements. For example, Malaysian Financial Reporting Standards (MFRS) are issued by the MASB in respect of its application in Malaysia (MASB, 2015).
\end{abstract}

Further, one of the most important objectives of financial reporting standards is to enhance transparency in providing financial statements. In this assignment, transparency is an important indicator to discuss on shareholders' trust. Practically, transparency helps in building and maintaining shareholders' trust. This is because the investors or shareholders seek for a reliable report in order to make a decision. With the adoption of the financial reporting standards, the reliability of the reports will be increased since the standards guide company in providing true and fair reports. In conjunction with the article we choose, our discussion will focus on financial reporting standards and its influence towards the shareholders' trust.

\section{BACKGROUND OF THE STUDY}

The article is describe about the tools that company can used to be good corporate governance is true and fair in financial reporting. According to this article, the financial accounting information is the product of corporate accounting therefore to be a good corporate governance the company should disclose their financial statement and the information of company clearly and true. The transparency information of company can help the third party like shareholders, investor, creditor and person are interested to company are more understand and interesting to be part of company by invest the capital to the company. 
Furthermore, this article also have discuss about the fees to auditor which is the company should give the reasonable fees to avoid "defensive auditing". Besides that, it also said that the transparency of information can help manager to be more efficient and effective to control of corporations and it is fair to the shareholder and investor because of knowing the detail of their investment.

There are six main points in this article which is accounting and corporate governance, transparency through auditing of developments in UK, financial transparency in the company's act, 1956 in India, role of the auditor in corporate governance, recommendations of the companies bill 2011 at India and adoption of international accounting standards. In point accounting and corporate governance is to be good corporate governance the capital of company should separate from ownership to avoid misunderstanding and confuse in amount of capital and easy to control. Besides, the director should alert and aware the accuracy information of financial position before disclose to shareholder or third party. Second main point is focus on the development of company act, it showed the development of companies act in UK and it is related with what the company should have to create good corporate governance in their company. It is quiet same with the third point where it describes the companies act in India where the company should prepare the detail of their company for company affair and shareholder.

Next point is role of the auditor in corporate governance which is in this part it tells detail about the role of auditor, what the action of auditor should do if fraud happen in the company, and how the auditor should provide the opinion to the company with the evidence. After that is recommendation of the company bill, 2011 in India. This point tells us in India, the public companies are obliging to appoint an independent director and the director also should appointed the audit committee in the company. Last point in this article is adoption of international accounting standards, it tells India should use and adopt the international accounting standards (IAS) in Indian accounting standard to upgrade their corporate governance.

\section{PREVIOUS DISCUSSION}

The developments of companies act in this article focus to UK and India. The development of companies act in UK that discuss in this article is around 1862 until companies act 2006. Companies Act 1862, audit is not important for the company and costly to company. In 1907 , it stated that the balance sheet should include in annual report. The financial statement was emphasize again on companies act 1929 which is before start general meeting, the director should provide or disclose the balance sheets and profit and loss accounts. The development of companies act can see on 1947 when the appointed of auditor and disclosure the account. On companies act 1948 and 1981 we can see that, to be good governance the company should prepare the detail and complete of financial report where the balance sheet should show the detail of share capital, reserves and liabilities of the company. Besides for large company they also should disclosure account statement for their subsidiary too. Furthermore, the balance sheet that provide should true and fair and follow the format when prepare it which is the report should have notes for the detail. This act showed that the company should make their financial report transparent to investor and company affair. Besides help the investor see the performance of company easily and attract them to invest. The companies act of UK is develop, when the content is related with director remuneration, pension and 
compensation for loss of office and loan on companies act 1985. Companies Act 1989 stated that the account statement should distribute to the member of meeting before 21 days of general meeting. The company should recognize the statutory right of the members to receive annual report of company was stated in company act 2006.

According in this article, in India there are not more act in the financial transparency if compare in the UK. The Companies Act 1956 in India it refer to Bhaba Committee and Shashtri Committee that stated that the information that prepare by company should understandable by shareholder and every opinion from the auditor should state in the annual report. This act also state that the shareholder have power to appoint auditor and the role of auditors is authenticating the report. The companies act 1862 state the company should appoint the auditor to trace any fraud or error in the company. It showed that the companies act at India and UK is same on the transparency of report where to create a corporate governance in the company, the company should make sure the detail of their company are transparency.

\section{METHODOLOGY}

In completing this assignment, an article that relates to the relationship of financial reporting standards and its influence towards shareholders' trust has been analyzed. The process of finding the relevant article has been done through searching the Emerald Insight website. Besides, the statistical analysis also been carried out. By having this statistical analysis, we got the information about the countries that adopt IFRS and not. Last but not least, we also did the comparative analysis where we compared with other articles in order to give better recommendations for the lacks that consist in our chosen article, True and Fair Financial Reporting: A Tool for Better Corporate Governance.

\section{DISCUSSION AND RECOMMENDATION}

In conjunction to the chosen article, True and Fair Financial Reporting: A Tool for Better Corporate Governance, there are several points that attract our attention. Thus, this Section 5.0 will discuss about transparency in India, accounting and corporate governance, role of the auditor in corporate governance and recommendations accordingly.

\section{Transparency in India}

From previous study, this article shows that India had develop in the context of transparency. The provisions of Indian companies Act 1956 has been improved where it is compatible with the provisions of English Act. By having this development in financial disclosure, it shows a good action has been taken by India in order to enhance transparency. Unlike before, information disclosure has been misinterpreted as it might give advantage to the competitors as the information been disclosed to public. Hence, Indians were basically acted conservative according to this issue. The companies were not preparing the financial statements in a good manner. This situation led to certain problems like it gave hard time for the investors to understand the reports and make good decisions. According to this issue, it is recommended that the conservatism attitude in information disclosure is no longer exists. In addition, India or other countries are advisable to keep upgrading its provisions or requirements of the financial disclosure in regards to current situation. This enhancement in financial disclosure will not only benefits the investors or shareholders, but will also benefits the company itself. 


\section{Accounting and Corporate Governance}

Corporate governance is a system of rules, practices and processes in which the company is directed and controlled. Corporate governance basically involves balancing the interests of many stakeholders, such as shareholders, management, customers, suppliers, financiers, governments and communities. In this article, there are some content related to corporate governance. For example, Directors owe a duty to give correct information about the financial position of the company to the investors, oversee, supervise and monitor the company accounts prepared by the auditors, Need for appointing an independent auditor and audit committee to scrutinize, verify and supervise the accounts prepared by the internal auditors. There are still plenty of good corporate governance that must be implemented by the company to maximize profits and increase the efficiency of corporate governance.

Good corporate governance begins with a clear and flexible strategy for the organization. Clear strategies will facilitate the workforce to focus on and understand the company's mission and thus meet the users' needs. Flexible strategies will help companies deal with problems with various strategies that are appropriate. Even with a great and clear strategy, competitors can still steal customers, unexpected catastrophes that may possibly paralyze the company's operations, and unstable economic conditions. This is a risk that should be taken into consideration by the management. Risks cannot be fully addressed as it is important for companies to implement strategic risk management. For example, companies can diversify their market and company operations so that the company does not rely solely on one. Corporate policies are only effective when implemented. Implementation requires high discipline from all levels of management. Managers need to encourage their employees to better and achieve the company's mission but it must be acknowledged that heavy workloads and persistent stresses will have a long-term impact on the company.

Companies need to be fair to employees and to appreciate them. Companies need to be fair and ethical to customers to avoid losing customers. Corporate transparency is vital to the survival of the company. Sometimes managers limit information to stakeholders in the interests of the company. But corporate sincerity helps the company to operate more smoothly as employees have enough information about the company's financial performance. Transparency is also important to the public, as the public will know more about the company's actual situation.

\section{Role of The Auditor In Corporate Governance}

An auditor is an official whose job it is to carefully check the accuracy of business records. An auditor might be either an internal auditor, external auditor or independent auditor for accounting firms in the public or private sector. There are several points related to the role of the auditor in corporate governance in the article. There is a role of auditor to be taken into consideration by the company. One of the main roles of auditors in corporate governance is to protect the interests of stakeholders, especially shareholders. This is because audit reports especially external audit are conducted without influence from the company. The auditors also report the company's financial situation more sincerely and prove the validity of the financial 
statements issued by the company. The auditors also ensure that the board has accurate and credible information. The board can also question the views on the suitability of the existing financial principles of the company.

Further, the auditor may also introduce the policies and measures that are designed to increase accountability within the company. For example, the auditor may propose the company to impose penalties on officials who have manipulated the company's finances for their own benefit. Penalties can be dismissal and loss of all privileges such as compensation bonuses and pensions. Apart from that, the auditors can also assist in enhancing corporate governance by conducting assessments of risks that may be in the company. The auditors will assess the effectiveness of existing security measures against fraud and corruption. The auditors will also review the company's overall operations to identify potential leakage spaces. And assessments and suggestions can be given to the board to make corrections done to improve the quality of work.

External auditor could help ensure that good corporate governance by developing a crisis management plan to deal with the problem in the case of fraud, abuse of power and corruption in the interests of the individual. The plan usually has different responsibilities to the officer so that the risk of fraud will be reduced. With this, shareholders will be more confident company managements. The external auditor helps the company maintain a strong relationship with the regulator. Most regulators will be more supportive of companies and agencies with integrity in governance. The auditor assesses the company whether the company has followed all the rules and regulations and all accounting standards. The liaison officer and the stakeholders will further rely on disclosure and the company's accounting statements after the auditor proves its validity.

\section{CONCLUSION}

In this era of globalization, there are lots of business activities that occur every day either inside the country or globally. Basically, this business activity requires a proper financial presentation like financial statements in order to be easily assessed by the users. In this context of financial presentation or reporting, the demand for a good, high-quality, understandable, enforceable and globally reporting is increased nowadays. Regarding this, the reporting standards like International Financial Reporting Standards have been established as to guide the company to prepare the good and fair financial statements. These reporting standards are not merely to guide the company in reporting, yet it is objectively designed as to enhance the transparency which could build the shareholders' trust.

Further, from the findings of this assignment, it shows that financial reporting standards have influence towards shareholders' trust. Its influence is proven when the standards lead to a high-quality reporting. High-quality reporting means that a true and fair financial statement has been prepared. Technically, a true and fair reporting is really important in gaining and maintaining trust of the shareholders. Furthermore, as focused by True and Fair Financial Reporting: A Tool for Better Corporate Governance article, India itself had a major reform in its company law for the year 2000 in order to encourage the companies to have a clear disclosure. This is because India believed 
it could help to build the investors or shareholders' confidence towards the companies. Besides, a true and fair reporting shows that the reports are reliable. This element of reliability is what needed by the investors or shareholders in order to make decisions. Hence, the shareholders' trust also built as the reports are reliable.

However, there are some discrepancies in the standards that available in this entire world. Some countries have fully adopted IFRS while some not and partially adopted IFRS. For example, India has not yet formally committed to adopting IFRS Standards (IFRS Foundation, 2017). In this case, as per our opinion, it is recommended for the countries to adopt IFRS. As supported by Emergence of International Financial Reporting Standard in India's Accounting Scenario article, the use of IFRS is likely to enhance the reliability and image of financial reporting by Indian (and other countries) industry across the world, since it will be based on a global set of accounting standards (Sabrapiya, 2011). In addition, the financial statements' comparability which may influence business decisions will also be enhanced. Even though there might be some challenges to converge into IFRS, it surely can give better results in future. Hence, the company will also be benefited once it gains the trust from the shareholders.

\section{REFERENCES}

Pallisserry, F. (2012). True and Fair Financial Reporting: A Tool For Better Corporate Governance. Journal of Financial Crime. Vol. 19 Issue: 4, pp.332-342

IFRS Foundation. (2001). About Us. Retrieved from http://www.ifrs.org/about-us/who-weare/

MASB. (2015). Malaysian Financial Reporting Standards. Retrieved from http://www.masb. org.my/pages.php?id=89

IFRS Foundation. (2017). IFRS: India. Retrieved from http://www.ifrs.org/use-around-theworld/use-of-ifrs-standards-by-jurisdiction/india/

Investopedia. (2018). Corporate Governance. Retrieved from https://www.investopedia.com/ terms/c/corporategovernance.asp

Investopedia. (2018). Auditor. Retrieved from https://www.investopedia.com/terms/a/auditor .asp 